\title{
Multicriteria analysis of the quality of teaching process in higher education: how to evaluate implementation of critical thinking
}

\author{
Marko Hell ${ }^{1}$, Ante Knežević ${ }^{2 *}$ and Zoran Babić ${ }^{3}$ \\ ${ }^{1}$ Faculty of Economics, Business and Tourism, University of Split, Cvite Fiskovića 5, 21000 Split, \\ Croatia \\ E-mail: 〈marko.hell@efst.hr〉 \\ ${ }^{2}$ Faculty of Economics, Business and Tourism, University of Split, Cvite Fiskovića 5, 21000 Split, \\ Croatia \\ E-mail: 〈akneze04@live.efst.hr〉 \\ ${ }^{3}$ Faculty of Economics, Business and Tourism, University of Split, Cvite Fiskovića 5, 21000 Split, \\ Croatia \\ E-mail: 〈babic@efst.hr〉
}

\begin{abstract}
One of the main goals of any higher education system is developing students' critical thinking. Critical thinking contributes to decision-making and problem-solving skills, whether for professional or personal purposes. Teaching, on the other hand, has been largely influenced by new information technologies which have changed some of the related concepts and tools. The quality of the teaching process is multidimensional which is why no single unit of its measurement has been developed yet, in spite of numerous surveys that have collected massive amounts of information from the existing practice. The aim of this paper is to establish the most appropriate higher education quality measure, which would consist of all relevant indicators from different aspects, including implementation of critical thinking in the teaching process, weighting by two main groups of participants in the process - teachers and students. Multicriteria decision-making has been recognised as a suitable framework for achieving this goal. In fact, the problem of measuring teaching staff performance could be set up as a classical problem of multicriteria decision-making. With this approach the quality of teaching process should be simultaneously estimated by $n$ quality assurance criteria and in accordance with those criteria $m$ alternatives (professors) would be ranked or estimated.
\end{abstract}

Keywords: development of critical thinking, multicriteria analysis, teaching process evaluation, quality measures

Received: November 20, 2020; accepted: January 14, 2021; available online: June 29, 2021

DOI: 10.17535 /crorr.2021.0002

\section{Introduction}

Educational system is a large, complex and 'living' system in which rapid development of science and technology allows no time for long-term adaptation. Changes introduced with the purpose of harmonization with the highest standards of excellence must be fast and efficient. Recently, transformation of educational processes has been further accelerated by new and unexpected conditions caused by COVID-19 and the ensuing epidemiological measures. The situation required such changes that would meet the requirements of the epidemiological measures and at the same time allow for an ongoing and undisturbed operation of the educational system.

${ }^{*}$ Corresponding author. 
Compliance with the epidemiological measures reduced the spatial capacity of higher education institutions which resulted in part of the teaching being held at a distance. However, the implementation of changes cannot be based on the existing teaching methods which are not effective under new conditions and could potentially reduce the efficiency of the entire higher education system. Replacing 'traditional way of teaching' with distance learning involves implementation of a series of new tools such as forums, chats, quizzes, workshops in the teaching process where both teachers and students have to respect all pedagogical norms. Such a dramatic shift in the approach to teaching provided new opportunities for improving methods aimed at developing students' critical thinking (CT).

\subsection{Quality of higher education}

By 2025, the projected global demand for higher education could reach 263 million students. This represents an increase of 163 million students in the last 25 years (since 2000). Increase in demand for higher education is accompanied by a growing demand for quality assurance that can be a driver for institutions to achieve excellence in higher education [23]. There are several aspects of quality that are important in higher education - teaching process as a whole, teachers' qualities, students' qualities, quality of literature and ways of adopting new lectures. The quality of the teaching process in higher education is achieved through curriculum planning, choosing relevant content and developing students' competences. Planning, organising and implementing the teaching process requires adopting a multidisciplinary approach. Students should be equipped for lifelong learning and should develop the ability to apply theoretical knowledge to devise solutions to everyday practical problems [10].

The authors add several more criteria to this first aspect of quality - the course workload is in accordance with the assigned ECTS credits, the harmonization of all forms of teaching has been achieved, the method of knowledge assessment is appropriate and in accordance with the anticipated skills and competencies, and the teaching process provides time and opportunities to practice critical thinking. In terms of teachers' qualities it is important that the teacher is highly proficient in the course content and is well prepared for teaching, that he/she answers questions regularly and clearly, connects theory with the practical examples, leads the teaching process efficiently using both his/her own materials as well as external sources. It is important for teachers to have good communication skills and to be able to create a pleasant teaching atmosphere (risk-free environment excluding mockery). In addition, he/she must be available to students for individual discussions during office hours, allow students to think and theorize, be objective and promote the active involvement of students in the learning process (enhancing critical thinking) [4, 28]. Students, according to [28], need to develop self-confidence and awareness of the value of their opinions and ideas, they need to be actively involved in the teaching process, listen to a variety of opinions with respect and express their own judgement, but also in some cases refrain from it.

Teaching materials are a prerequisite for the success of education. According to [10] higher education teachers are able to (among many other things) design and prepare both teaching materials and assessment materials to evaluate students' achievements. Mandatory teaching literature and materials from alternative sources need to be available to students in order to enhance their acquisition of factual knowledge and encourage thinking. Quality also depends on lectures availability in video form. Last but not least are the ways of adopting new lectures through classes, reading, multimedia, demonstration and practice, group discussion, team projects, peer - teaching and applying what has been learned, self-evaluation. Consequently, application of scientific methods and modern technologies is unavoidable in the quality management of higher education systems because it allows an even distribution of responsibility 
based on timely, independent and inexpensive procedures in excellence testing.

\subsection{Improving the quality of the teaching process}

Modern higher education processes are learner-centred which is a crucial prerequisite for effective learning. Learner-centred education demands appropriate methodologies that can be used by teachers to provide a variety of learning experiences [1]. However, formal acceptance of some education models is not sufficient for enhancing effectiveness. Achieving a high quality of teaching has never been as challenging as it is today and the challenge has encouraged new trends in higher education, which cross both institutional and national borders [24]. This is why Croatia cannot and does not want to avoid these global trends, especially those that lead into European flows. In that context speed, effectiveness and excellence are its basic orientation model.

This study presents a model for evaluation of quality of educational activities and its application in the observed institution. The general hypothesis is that the model conceived in this way can equally well support processing of the given excellence parameters of multiple aspects of education. Consequently, the paper is a contribution both to the basic research in the field of operational research (particularly usefulness of multicriteria analysis) as well as to the assessment of adoption of information-communication technologies in education. Verification and validation of the model is carried out on the example of excellence indicators processing in accordance with the current achievements in this field.

Previous improvements will be embedded in a newly developed model that will evaluate the quality of the teaching process with the aim of developing students' critical thinking skills as a basic prerequisite of employability. Namely, as mentioned above, the current ways of determining the quality of teaching observe partial segments such as student satisfaction with the teacher's attitude, teaching or examining the possibilities of developing critical thinking skills among students. We believe that incorporating different aspects into a single model of the teaching process quality is possible by applying the multicriteria decision-making. Thus, the quality of teaching will be viewed from a process approach, i.e. the teaching process will be viewed through the roles of all stakeholders: future employers of current students, students as end users of the teaching process who need to acquire knowledge and critical thinking in the most appropriate way, and teachers as owners of the whole process. Also, it is highly important to mention that this paper is oriented towards students and their preferences and it assumes that learning outcomes set by teachers are aligned with the needs of employers as a result of standard procedure defined by Croatian Qualifications Framework. Therefore, the proposed model should result in the harmonization of wishes of all stakeholders that are included in the learning process. Furthermore, the use of the AHP method will enable combining students' subjective preferences and teachers' objective assessments of the possible applicability of students' preferences in the teaching process, all in accordance with the desired teaching goals set by employers.

\section{Integration of the elements of the teaching process}

Formal education, as we have known it so far, is losing its purpose in the age of the Internet and available online materials that enable individuals to learn independently $[5,18,13]$. This is a mitigating circumstance that allows most of the work to be transferred to the students during the distance learning period. Critical thinking should be seen as a basic academic competency, akin to reading and writing, which needs to be taught [12]. 


\subsection{Process approach to higher education}

A process is simply something actors in that particular process do to get something done (completed). Accordingly, process approach entails considering all the activities and perceiving them as sets of inputs and outputs. For every process it is very important to understand how it is done, when it is done, who does it, what is needed to get it done and how do you know it is working effectively [26]? In higher education, we recognise three major stakeholders - employers, teachers and students. Authors also emphasize this particular process because they want to include critical thinking (skills) in existing evaluations. Where information and communication technology (ICT) is implemented in the teaching process we distinguish between two main approaches to teaching/learning: face-to face (F2F) learning (less use of available technology) and distance learning that includes e-learning and traditional distance learning (with more use of available technology) [9, 28]. The ultimate goal is to bridge the gap between students' current knowledge and employers' requirements. This paper assumes that the requirements of the employers are aligned with the curriculum, which implies that teachers know what they need to teach their students. On the other hand, teacher has to be adapted to the students without lowering the criteria of successfully acquired knowledge. Moreover, new research implies that critical thinking is one of the most important determinants of high education.

\subsection{Developing student critical thinking}

It is often suggested that there are two relevant characteristics that are important for the success of an academic program - facilitating critical thinking and encouraging a variety of intellectual styles [14, 17]. Critical thinking enhances decision-making and problem-solving skills whether in professional or personal matters and it is thus crucial that the instructors recognize the importance of developing such skills in their students. Discussions of the responsibility for teaching students to use higher level thinking skills has been on educators' agenda since the 1980s [29]. There are many teachers that support the concept of critical thinking and its implementation in curriculum, but at the same time they lack confidence or fear the lack of capacity to do it. Finally, in exam-oriented cultures there is a huge emphasis on learning the facts and information to excel on tests and usually that harms development of creative and critical thinking abilities [22]. Research findings support the idea that such skills can be taught and developed, i.e. that students can improve their quality of thinking if schools adopt critical thinking strategies and techniques [3].

CT skills usually involve five segments: determining the reliability of sources, argument, prediction, causal explanation and determining parts-whole relationships. Likewise, the very construct of $\mathrm{CT}$ is seen as consisting of seven dimensions: truth seeking, open-mindedness, analyticity, systematicity, CT self-confidence, inquisitiveness and maturity [30]. It is suggested that pedagogical skills such as background knowledge, thinking strategies and habits of the mind are crucial in improving critical thinking skills among students [19].

Even though development of CT skills is recognized as one of the most important goals in education, there is very little evidence to help teachers decide how to enhance them [16]. In addition, it often seems that teachers do not practice the four learning processes: assumption analysis, imaginative speculation, contextual awareness and reflective scepticism. This suggests that in education CT skills are practised only to a very small extent [7]. Literature indicates two possible ways of introducing critical thought in education: 'build in' instructions with critical thinking skills incorporated into the content matter or explicit instructions with specially designed lessons to provide guidelines in critical thinking skills [16]. 
It is of great importance that teachers involve students through questions, discussion and reflection. Active learning methods offer the best solution in support of critical thinking. For example, if students have time to ponder the question, discuss it in teams or elaborate their answers to others, they are far more likely to use critical thinking skills at more advanced levels of Bloom's taxonomy [22].

The empirical research proposes that positive mood can have beneficial effects on problem solving and cognitive flexibility [15]. Moreover, it is suggested that there are three kinds of classroom interaction that are influenced by instructors: the extent to which faculty members encourage or use students' ideas, the cognitive level and the amount of student participation, and last but not least is the amount of discussion among students in the classroom. Some even suggest that it is far more important what students do for courses than how teachers teach their courses. Teachers need to learn how to organize the class presentation, how to formulate and ask questions, and how to give clear explanations about the abstract themes. They also need to pay attention to course assignments or exams and their importance to the course, which requires determining the specifics of the assignments and making sure they incorporate 'extraction of diverse ideas from multiple sources' [27]. When considered in the context of developing CT skills teachers can be seen as differing in terms of: (i) their attitude towards critical thinking, style of thinking and competence; (ii) the way they approach the teaching of CT skills; and (iii) the way they organize the teaching content [6]. Finally, it is important that the lever between students and teachers is in balance, i.e. that both sides contribute to the development of critical thinking.

According to Bloom's taxonomy, students need to implement a wide range of intellectual abilities 'remember' (knowledge), 'understand' (understanding), 'apply' (application), 'analyse' (analysis), 'evaluate' (evaluation) and 'create' (synthesis). These should be encouraged by teachers in course of teaching and exam sessions [20]. In order to achieve this teachers need to ask students to: recall the information, provide explanations, demonstrate ideas or opinions, make an analysis, assess, and think of other potential approaches to the task [21]. Nowadays, Learning Management Systems (LMS) allow teachers to better understand and serve learners. For example, critical thinking in Moodle-based LMS can be achieved in multiple ways - through Forums, Quick Messaging, Additional Resources, Industry Exposure, Quality Assessments and Feedback [11].

\subsection{ERR model as an example of a process for development of CT}

Evocation, Realization of meaning, Reflection (ERR) model was first described by Vaughn and Estes in 1986 and it was modified by Meredith and Stelle in 1997. The models' basic features are closely related to encouraging critical thinking and in-depth processing of information. In the evocation phase, the goals are to connect existing knowledge with new knowledge and motivate students for the new lecture. In the realization of meaning phase, students come into contact with new information that they should adopt, while in the reflection phase students think about what they learned and strengthen the connection between new knowledge with the existing one [2]. Teachers' tasks in each of the phases will be listed down below. It should be noted that discrepancy between the teaching style and the students' learning style can be a reason for failure in learning, along with the common problems of insufficient motivation and prior knowledge [8]. In the evocation phase, the teacher asks for active participation in the repetition of the material on the teaching topic, motivates students for the topic, successfully raises students' awareness of their existing knowledge required for processing the topic, and introduces the goals of the teaching unit. Secondly, in the realization of meaning phase the teacher motivates and helps students to construct their own knowledge about the teaching unit, transfers his/her knowledge to the students through the lecture, and cooperates with students in interpreting the teaching 
material by requiring interaction if/when necessary. Thirdly, in the reflection phase teacher relates the previous knowledge with the new material/new topic, asks students to present new information in their own words and encourages the exchange of ideas among students. The ERR model is not difficult to adapt to teaching content if the teacher is motivated to improve the quality of teaching and to encourage the development of critical thinking and active learning among students [2].

\section{Integrate approach based on multicriteria analysis}

Currently, the world is living under new conditions, often referred to as the 'new normal', caused by the COVID19 epidemiological measures. These measures, along with the other turbulent changes in social phenomena, require application of universal techniques and methods. In this chapter, the process of determining a holistic view of the teaching process quality will be presented, based on the previously conducted analysis.

\subsection{Defining the set of indicators for quality evaluation}

The first step is to determine what has to be obtained as the research output, i.e. what is the final result of the research and what changes have to be made. In accordance with that all indicators are defined. When choosing an indicator it is crucial to select an adequate number of them (if there are too many indicators they can 'suffocate' the problem solving process, but at the same time it is important that indicators crucial for final decision-making are not left out). In large systems, such as educational, sudden changes can lead to decline of efficiency in obtaining their goal. Moreover, educational systems cannot be interrupted to implement a change and then resumed. Changes have to be made along the way [4].

Considering the experience of advanced systems of higher education an expert team has to define groups of excellence indicators. From the empirical materials, factors are selected that best coincide with the 3 basic dimensions that authors find equally important (listed down below).

\subsubsection{Desired teacher profile}

The owner of the whole teaching process is the teacher, which makes it essential to determine teacher qualities, including the features that surface during the distance learning period. The criteria to determine the desired teacher profile were established based on a range of questionnaires and student experience during direct classroom teaching and distance learning period. The criteria are organised in sets as indicated by Figure 1, which presents only the section that refers to teachers (from number 11). The section with sets from 1 to 10 refers to the student profile which is not the focus of this paper. 


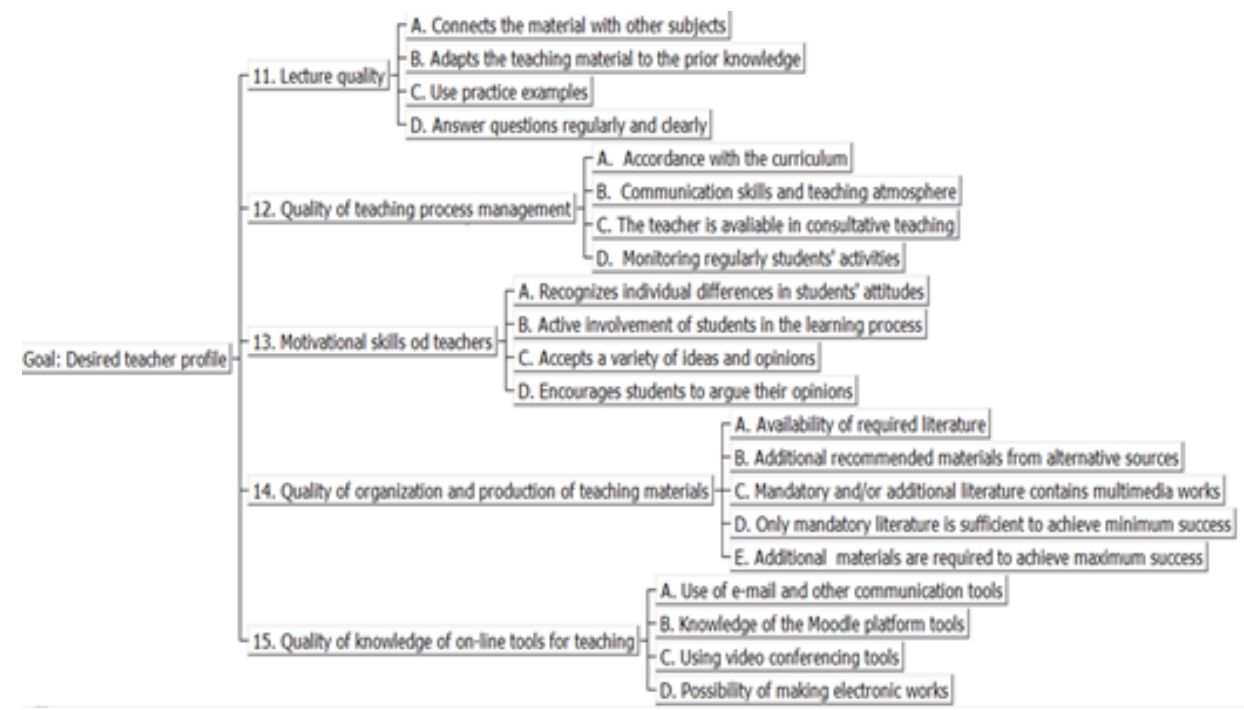

Figure 1: Desired teaching profile in Expert Choice

Five sets of parameters were developed to determine the desired teacher profile: lecture quality, quality of teaching process management, teacher's motivational skills, quality of organization and production of teaching materials and last but not least proficiency in applying on-line tools for teaching. Students were required to assess each criterion listed according to the level of importance. It turned out that 'lecture quality' received the highest average grade while the lowest was assigned to 'proficiency in applying on-line tools for teaching'.

\subsubsection{The importance of each teaching phase}

Given the importance this study is assigning to developing students' CT skills, ERR framework has been selected as an excellent example of a process that facilitates this endeavour. Methods and techniques were developed for each phase of the ERR model - revision of the old material required for the adoption of the 'new' material, transfer of the 'new' material and linking the 'old' and the 'new' material. Sets of methods developed by the authors are shown in Figure 2.

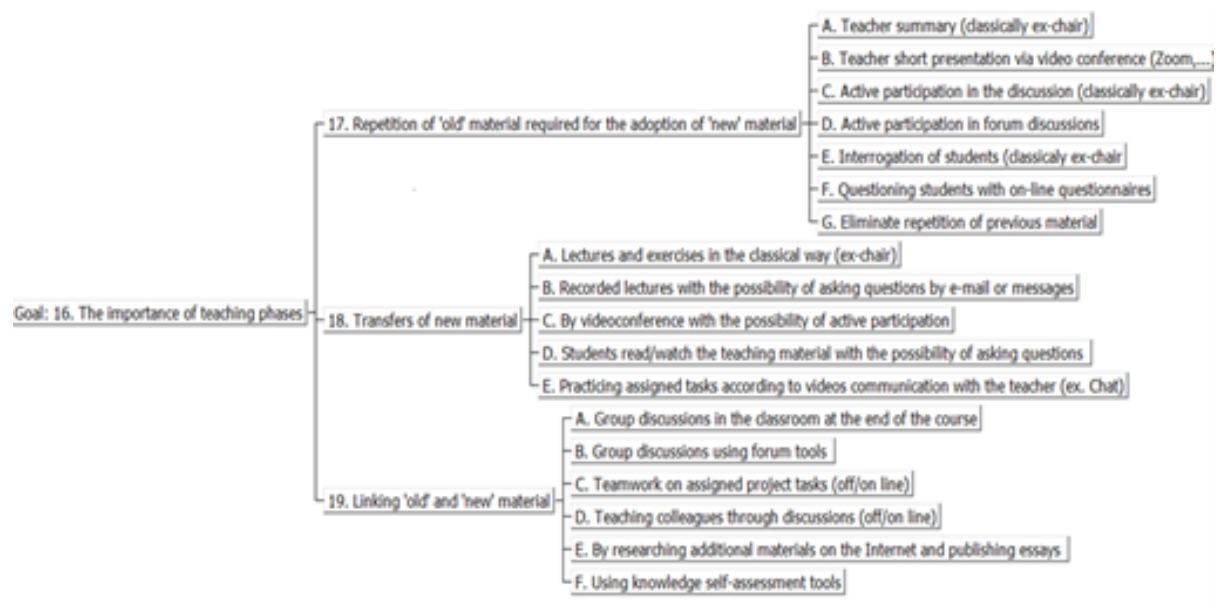

Figure 2: The importance of 3 teaching phases in Expert Choice 


\subsubsection{Assessing the learning outcomes}

Last activity in the teaching process is checking (assessing) students' acquired knowledge. This activity is equally important for students as it is for teachers. For students it is a proof of achievement of the desired level of knowledge and for teachers it is a way of identifying the possible improvements of the existing and previously adopted activities in order to achieve better student success. In this way the improvement of the whole teaching process is achieved. The goal of assessing students' learning outcomes has been grouped into 2 sets of criteria - the continuity of checks and verification methods (as shown in Figure 3).

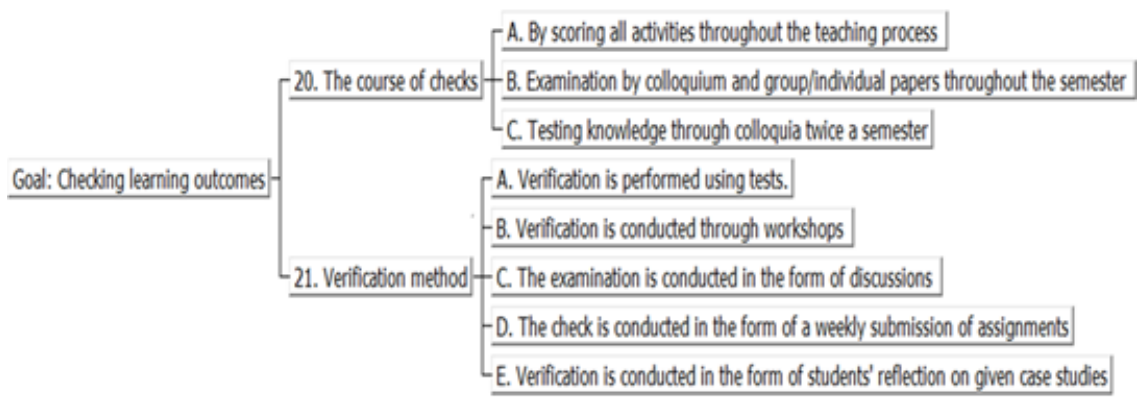

Figure 3: Checking learning outcomes in Expert Choice

\subsection{Subjective estimating of indicators' weighting according to stu- dents' preferences}

Second step is weighing the indicators. In this procedure, one should be cautious of not assessing "all indicators as equally important" as well as of allowing simplified assessments made by individuals prone to "weight" the indicators by themselves. Modern decision-making theory argues that the methods based on pairwise criteria evaluation are most acceptable and that they are more objective than those by which the decision-maker determines the importance of all objects in one step. As already stated, the process approach focuses on user satisfaction. In this case this is student satisfaction which is why they need to be involved in weighing the indicators. Their subjective assessment of weight values of the indicators will reflect their preferences in terms of the elements of quality - teachers' quality, quality of the entire teaching process, as well as the quality of the assessment of the learning outcomes. Thus, the quality criteria are adjusted to the users' subjective requirements. It is important to note here that this is not about determining the level of the learning outcomes that students are required to achieve, (which is defined by the curriculum) but only about the method that is or will be used.

In order to gather the necessary data a 22-item questionnaire was developed and administered via the Internet. The first 10 questions aim at determining student profiles. Each of the remaining 12 items consists of a set of criteria that students had to assess on the scale from 1 to 5 ( 1 being the lowest and 5 the highest grade) based on the importance they attach to them. These 12 questions are the focus of this research paper and they are important to determine the three goals presented in figures 1,2 and 3 :

- desired teacher profile,

- the importance of teaching phases and

- checking the learning outcomes. 
Total weight of each criteria in the groups was calculated as the arithmetic mean of values that were assigned by all students. This gives an order of criteria according to the students' subjective preferences.

\subsection{Objective assessment of students' preferences}

The third step is to assess the possibility of students' subjective preferences by the teachers. It is necessary to determine whether the students' preferences can be incorporated into the curriculum. Therefore, the teachers must further evaluate the student's preferences which leads to the objectivity of the model. For example, if a student considers the possibility of distance learning to be important, the teacher should evaluate the objectivity of its feasibility. To evaluate the importance of indicators and the formerly mentioned factors representing sets of indicators this paper uses one of the most respectable methods in that area, the analytical hierarchy process $(\mathrm{AHP})$. AHP, also known as eigenvector method as the first step in the analytic hierarchy process, as it is generally accepted, is one of the best methods for determining the criteria weights in any multi-criteria decision-making problem. This paper has adopted a hierarchical view of the problem of the quality of teaching process in higher education which makes AHP a particularly suitable method. Analytical network process (ANP), for example, structures a decision problem as a network, and is searching for complex and interrelated relationships between decision elements. This paper started from AHP for determining the criteria ponders, while in the second step, i.e. when the alternatives (teaching staff and their performance) are included, any other multi-criteria method (PROMETHEE, TOPSIS, ELECTRE) can be used.

The experts in the observed area (in this case - teachers) will provide assessments about how much a certain factor, or category, is better or worse than any other (pairwise comparison) which will result in the so called Saaty matrix of mutual comparison. Based on this matrix it is possible to calculate the final weight or importance of every factor by using an appropriate software (e.g. Expert Choice) [25]. In the same way, in the next step, evaluation of indicators within each category is carried out. The results of this study were calculated by Expert Choice and are shown in figures 4-6:

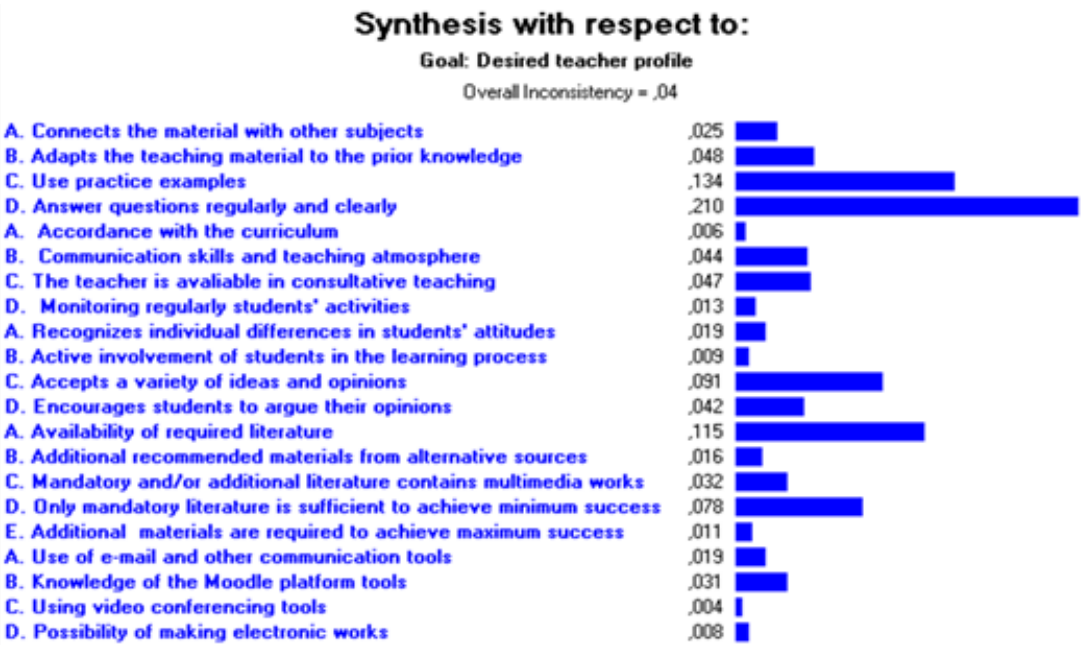

Figure 4: Desired teacher profile - weighting indicators 
Synthesis with respect to:
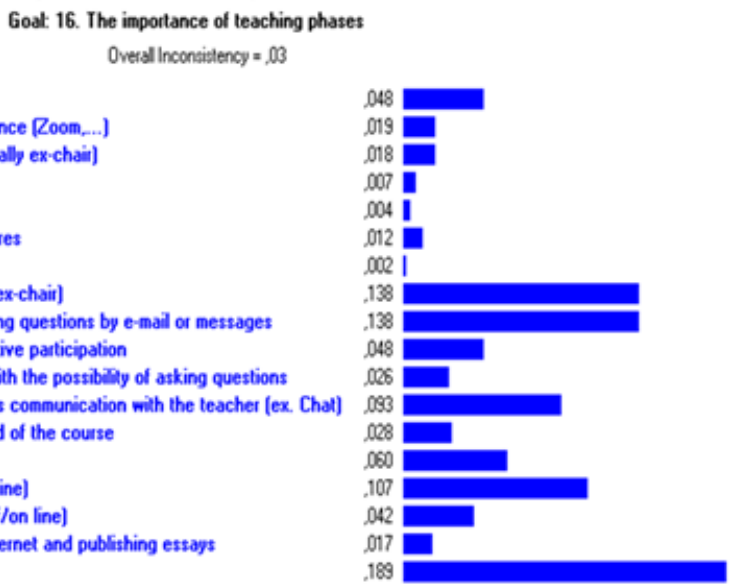

Figure 5: Teaching phases - weighting indicators

\section{Synthesis with respect to:}

Goat: Checking learning outcomes

Overal Inconsistency $=, 05$
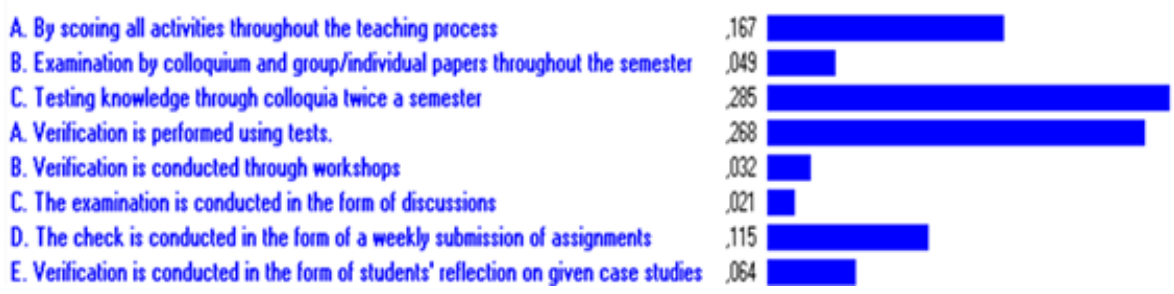

Figure 6: Checking outcomes - weighting indicators

\subsection{General model for implementation in the institutions of higher education}

The scores generated in this study are not universally applicable to every institution of higher education because all research data was collected at the Faculty of Economics, Business and Tourism in Split (Croatia). Therefore, the present paper does not discuss the results of the survey in great detail. However, the model developed and criteria presented can be applied at any institution of higher education by incorporating their own data (customized use of the model). Follows a summary of the most important features of this model. Firstly, it consists of three parts (dimensions): desired teacher profile, importance of each teaching phase (based on ERR framework) and checking the learning outcomes, each equally important. Criteria have been developed for each part of the model based on empirical research and student experience during the distance learning and direct classroom teaching. Firstly, students assess each criteria (on the scale from 1 to 5) based on their preferences (thus, applicability to all study programs is achieved). Secondly, experts perform a pairwise comparison, generate the so-called Saaty matrix and calculate the final weight of each criteria (using software like Expert Choice). After this step, weighting indicators are obtained for each criteria. In the next step, students have to assess the teachers again (but now they are giving grades to the teachers rather than the importance of the criteria). It is important to state here that if any of the methods is not 
applied by the teacher then a zero value is assigned to that criterion. According to this model, a teacher that applies more than one method in teaching has an advantage over the one who applies only one method. Lastly, final teacher grade presents the sum of the product of the coefficients of the criteria and the grade of the teacher. To conclude, the model was developed as a higher education quality measure that consists of all relevant indicators that are weighted by different actors (both teachers and students) which was the aim of this research paper.

\section{Conclusion}

The shocking development of the situation caused by the COVID19 crisis accelerated the process of introducing information technologies in higher education. The current circumstances indicate that the academic year 2020/2021 will continue to present challenges in terms of implementing the teaching process. In accordance with the official projections of the development of the current situation, it is expected that teachers should be prepared for various scenarios: F2F, distance learning as well as complete online teaching. The current obstacles will eventually be overcome and we will be able to choose our teaching preferences again. This time we will be able to choose from a wider range of options that we have mastered in this daunting period. Undoubtedly, it will be necessary to use the new knowledge and skills about learning and teaching gained during this period. This paper has adapted its approach to end users, without lowering the criteria of successfully acquired knowledge. Likewise, the presented model formalized the way of evaluating the development of critical thinking as one of the students' essential skills after graduation. Finally, it is very important to mention that in the process of determining the quality of teaching processes weighting coefficients are used to weigh the student grades of teachers. The successfully developed model indicates that it is possible to include multiple aspects of quality of education in a single model which the hypothesis presented at the beginning of the paper.

\section{Acknowledgements}

For useful comments and suggestions we would like to thank the anonymous reviewers and the discussants at the 2020 KOI conference in Šibenik. Also, we want to thank all 302 students at the Faculty of Economics, Business and Tourism who responded to our survey.

\section{References}

[1] Aithal, P. S., and Suresh, K. (2016). Teaching - Learning Process in Higher Education Institutions. International Journal of Modern Physics A, 2(1), 662-676. https://ssrn.com/abstract=2800585

[2] Akalović Antić, J., Harmina, A., and Meter, J. (2016). Primjena ERR okvira na nastavnu jedinicu: aritmetička sredina. Poučak: časopis za metodiku i nastavu matematike, 17(65), 5-20. https://hrcak.srce.hr/169554

[3] Alwehaibi, H. U. (2012). Novel program to promote critical thinking among higher education students: empirical study from Saudi Arabia, Asian Social Science, 8(2), 193-204. doi: 10.5539/ass.v8n11p193

[4] Babić, Z., Hell, M., and Nikolić, N. (2007). High education quality and multi-criteria analysis. Global Business \& Economics Anthology, 1, 509-516.

[5] Bonetta, G., (2011). Educational change and digital frameworks. Digital Technologies and New Forms of Learning (ed. J. Milat). Split: Faculty of Philosophy University of Split, (pp. 41-49).

[6] Buchberger, I., Bolčević, V., and Kovač, V. (2017). Kritičko mišljenje u obrazovanju: dosadašnji doprinosi i otvoreni smjerovi. Metodički ogledi, 24 (1), 109-129. doi: 10.21464/mo45.124.109129

[7] Chee, C. S., and San Oo, P. (2012). Reflective thinking and teaching practices: a precursor for incorporating critical thinking into the classroom? International Journal of Instruction, 5(1), 167-182. http://www.e-iji.net/dosyalar/iji_2012_1_11.pdf 
[8] Cota Bekavac, M., Grozdanić, V. and Benge Kletzien, Sh. (2005). Aktivno učenje i kritičko mišljenje u visokoškolskoj nastavi. Priručnik za nastavnike - Suradničko i iskustveno učenje. Zagreb: Forum za slobodu odgoja.

[9] Ćukušić, M., and Jadrić, M. (2012). E-učenje: koncept i primjena. Zagreb: Školska knjiga d.d.

[10] Domović, V., Ledić, J., and Crnčić Sokol, M. (2018). Handbook for teaching competence enhancement in higher education. Zagreb: Ministry of Science and Education (Croatia).

[11] Duque, T. C. (2019). Critical Thinking In Moodle-Based LMS: The What, Why \& How. https://www.lmspulse.com/2019/critical-thinking-in-moodle-based-lms-the-what-why-how/ [Accessed 17.09.2020.]

[12] Fisher, A., and Scriven, M. (1997). Critical Thinking. Its Definition and Assessment. Edgepress: CA, USA/Centre for Research In Critical Thinking: Norwich, UK.

[13] Janković, V. (2011). Informacijsko-komunikacijska tehnologija u visokom obrazovanju: moćno oružje za što? Digital Technologies and New Forms of Learning (ed. J. Milat). Split: Faculty of Philosophy University of Split, (pp. 150-159.)

[14] Lefton, L. A. (1997). Why I teach the way I do: Repackaging psychology. In R. J. Sternberg (Ed.), Teaching introductory psychology: Survival tips from the experts (pp. 65-71). Washington, DC: American Psychological Association.

[15] Lewine, R., Sommers, A., Waford, R., and Robertson, C. (2015). Setting the mood for critical thinking in the classroom. International Journal for the Scholarship of Teaching and Learning, 9(2), 1-4. doi: 10.20429/ijsotl.2015.090205

[16] Marin, L. M., and Halpern, D. F. (2011). Pedagogy for developing critical thinking in adolescents: Explicit instruction produces greatest gains, Thinking Skills and Creativity, 6(1), 1-13. doi: $10.1016 /$ j.tsc.2010.08.002

[17] Marra, S. E. (1997). An exploration of critical thinking, learning style, locus of control, and environmental perception in baccalaureate nursing students. Dissertation Abstracts International: The Sciences and Engineering, 58 (3B), 1215.

[18] Matijević, M. (2011). Novi mediji i informalno učenje. Digital Technologies and New Forms of Learning (ed. J. Milat). Split: Faculty of Philosophy University of Split, (pp. 279-287).

[19] Moeti, B., Mgawi, R. K., Smitta, M., and Waitshega, T. (2017). Critical thinking among postgraduate diploma in education students in higher education: Reality or fuss? Journal of Education and Learning, 6(2), 13-24. doi: 10.5539/jel.v6n2p13

[20] Nimac, E. Primjena Bloomove taksonomije znanja u nastavi. https://www.azoo.hr/app/uploads/uvezeno/images/razno/E._Nimac.doc [Accessed 21.09.2020.]

[21] Norfleet, M. (2017). What Are the Steps to Critical Thinking According to Bloom's Taxonomy? https://classroom.synonym.com/steps-critical-thinking-according-blooms-taxonomy28811.html [Accessed 05.09.2020.]

[22] Razaei, S., Derakshan, A., and Bagherkazemi, M. (2011). Critical thinking in language education. Journal of Language Teaching and Research, 2(4), 769-777. doi: 10.4304/jltr.2.4.769-777

[23] Ryan, P. (2015). Quality assurance in higher education: A review of literature. Higher Learning Research Communications, 5(4). doi: 10.18870/hlrc.v5i4.257

[24] Saroyan, A., and Trigwell, K. (2015). Higher education teachers' professional learning: Process and outcome. Studies in Educational Evaluation, 46, 92-101. doi: 10.1016/j.stueduc.2015.03.008

[25] Saaty, T. L. (1998.). The Analytic Hierarchy Process. New York: McGraw Hill.

[26] Servan, P. (2019). Process-based Approach. https://factorquality.com/process-approach/ [Accessed 06.08.2020.]

[27] Shim, W., and Walczak, K. (2012). The impact of faculty teaching practices on the development of students' critical thinking skills. International Journal of Teaching and Learning in Higher Education, 24(1), 16-30. https://eric.ed.gov/?id=EJ977179

[28] Steele J. L., Meredith K. S. and Temple C. (1998). Okvirni sustav kritičkog mišljenja u cjelini nastavnog programa. Zagreb: Otvoreno društvo Hrvatska.

[29] Wallace, E. D., and Jefferson, R. N. (2015). Developing critical thinking skills: assessing the effectiveness of workbook exercises. Journal of College Teaching and Learning, 12(2), 101-108. doi:10.19030/tlc.v12i2.9187

[30] Zhang, L. (2003). Contributions of Thinking Styles to Critical Thinking Dispositions. Journal Of Psychology: Interdisciplinary And Applied, 137(6), 517-544. doi: 10.1080/00223980309600633 